\title{
Model pembelajaran empati untuk membangun sekolah berwawasan multikultural
}

\author{
Bambang Kariyawan Ys ${ }^{1}$, Mas'ud Zein $^{2}$, Rian Vebrianto ${ }^{3}$ \\ ${ }^{1}$ SMA Cendana Pekanbaru \\ ${ }^{23}$ Universitas Islam Negeri Sultan Syarif Kasim Riau
}

\begin{tabular}{l}
\hline Article Info \\
\hline Article history: \\
Received Apr $12^{\text {th }}, 2020$ \\
Revised May $11^{\text {h }}, 2020$ \\
Accepted Jun $26^{\text {th }}, 2020$ \\
\hline
\end{tabular}

\section{Keyword:}

Model of learning

Empathy

Education Multicultural

\begin{abstract}
The purpose of this study is to look at the steps of implementing empathy learning models that can build multicultural schools with insight. The method of research this is literature review with techniques to collect the data from a variety of sources written in the form of books, journals, articles science or literature review. The results of the research it is in the form of design models and the stages of implementation of the model of learning empathy that do teachers and outside the classroom in the form of an attitude accept differences in background behind the social culture of a person. Measurement of learning outcomes of empathy learning models is measured by authentic assessment in the form of observing attitudes and the process of interacting in groups, case studies, performance and portfolio.
\end{abstract}

(C) 2020 The Authors. Published by IICET.

This is an open access article under the CC BY-NC-SA license

(https://creativecommons.org/licenses/by-nc-sa/4.0

\section{Corresponding Author:}

Bambang Kariyawan Ys,

SMA Cendana Pekanbaru

Email: bkariyawan090571@gmail.com

\section{Pendahuluan}

Indonesia termasuk salah satu negara terbesar di dunia yang memiliki kekayaan keragaman sosial budaya (multikultural). Keadaan ini tercermin dari beragamnya suku bangsa, agama, ras, dan budaya. Kondisi keragaman bangsa ini bukanlah kondisi yang baru terbentuk. Realitas sejarah atas keragaman ini sudah berlangsung lama sejak lama. Permasalahan sosial yang dihadapi dari konsekuensi tersebut seperti hilangnya rasa kemanusiaan untuk selalu menghargai hak-hak orang lain, perseteruan politik, korupsi, kolusi, nepotisme, premanisme, kemiskinan, kekerasan, separatisme, dan perusakan lingkungan (Rambitan, 2012).

Dalam catatan perjalanan umat manusia, derita panjang umat manusia hadir sebagai efek negatif atas keragaman tersebut. Perjalanan panjang sejarahnya diwarnai pertikaian besar antar etnis. Hal utama yang mempengaruhi dan menyebabkan konflik panjang tersebut berupa faktor-faktor sentimen terhadap unsur SARA (Suku, Agama, Ras, dan Antar Golongan) (Ambarudin, 2016). Demikian halnya negeri kita Indonesia, dalam kurun waktu 20 tahun terakhir telah banyak terjadi konflik dan kerusuhan sosial bernuansakan SARA di berbagai daerah. Hingga kini ini konflik dan kerusuhan sosial dengan simbol-simbol dan sentiment agama dan suku bangsa masih terus berlangsung.

Beragamnya etnis, budaya, agama, dan latar sosial budaya lainnya di negeri kita realita yang tidak mampu ditolak. Kondisi keberagaman bangsa ini dalam teori ilmu sosial disebut sebagai masyarakat multikultural. Nasikun (2007) menjelaskan bahwa struktur horizontal dan vertikal masyarakat Indonesia memberikan ciri dan sifat yang unik. Perbedaan latar agama, suku bangsa, adat, dan kedaerahan telah menandai kenyataan dan kesatuan sosial horizontal. Sedangkan secara vertikal ditandai adanya perbedaan struktur masyarakat 
antara lapisan masyarakat atas dan lapisan masyarakat bawah. Kondisi horizontal dan vertikal inilah yang menandai masyarakat Indonesia bersifat majemuk.

Hal ini ditegaskan Furnivall (1939) yang menyatakan bahwa ciri-ciri masyarakat majemuk sebagai suatu masyarakat yang menganut dan memiliki sistem nilai dalam berbagai kesatuan sosial, sehingga anggota kelompok masyarakat terjadi homogenitas kebudayaan, kurang memiliki loyalitas, sebagai dasar untuk saling memahami satu sama lain.

Selanjutnya Suparlan (2002) memandang bahwa acuan utama bagi terwujudnya masyarakat multikultural adalah paham keragaman ini. Mengingat multikulturalisme secara individual maupun secara kebudayaan sebagai sebuah ideologi yang mengakui perbedaan dalam kesederajatan baik. Ulasan mengenai multikulturalisme mengulas berbagai permasalahan berupa politik dan demokrasi, keadilan dan penegakan hukum, kesempatan kerja dan berusaha, HAM, hak budaya komuniti dan golongan minoritas, prinsip-prinsip etika dan moral, dan tingkat serta mutu produktivitas.

Masyarakat manapun termasuk Indonesia memiliki kebudayaan dan corak mosaik yang berlaku umum menurut model multikulturalisme. Di dalamnya melingkupi unsur-unsur kebudayaan dari masyarakatmasyarakat lebih kecil sehingga membentuk masyarakat yang lebih besar. Paham keragaman (multikulturalisme) memerlukan sebuah bentuk tatanan kehidupan masyarakat yang damai dan harmonis dalam latar belakang yang beraneka ragam (Ambarudin, 2016).

Di sisi lain, melihat kenyataan keragaman tersebut, bangsa Indonesia memerlukan rekonstruksi kembali atas kebudayaan nasionalnya. Harapannya dapat menjadi keinginan yang kuat untuk bersatu yang telah mengikat seluruh keragaman etnis dan budaya tersebut. Untuk mewujudkan itu diperlukan pendekatan pemahaman atas keragaman. Sehingga akan terbangun suasana toleransi atas keragaman tersebut. Salah satu caranya dengan mengajarkan betapa pentingnya menghargai keragaman melalui pendidikan multikultural (Wahyuni, 2015).

Secara umum, pendidikan multikultural didasarkan pada prinsip keadilan pendidikan untuk semua siswa, terlepas dari budaya, dan berusaha untuk menghilangkan hambatan untuk peluang pendidikan dan keberhasilan bagi siswa dari perbedaan latar belakang budayanya. Dalam praktiknya, pendidik mampu memodifikasi atau menghilangkan kebijakan, program, materi, pelajaran, dan praktik pendidikan yang bersifat diskriminatif terhadap atau tidak cukup inklusif dariberagam perspektif budaya. Pendidikan multikultural juga mengasumsikan bahwa cara-cara di mana siswa belajar dan berpikir sangat dipengaruhi oleh identitas budaya dan warisan mereka, dan bahwa untuk mengajar siswa yang beragam budaya secara efektif memerlukan pendekatan pendidikan yang menghargai dan mengenali latar belakang budaya mereka. Dengan cara ini, pendidikan multikultural bertujuan untuk meningkatkan pembelajaran dan keberhasilan semua siswa, terutama siswa dari kelompok budaya yang secara historis kurang terwakili atau dari kelompok yang pencapaian pendidikannya lebih rendah (Sudrajat, 2014).

Pendidikan multikultural akan berjalan sesuai harapan bila didetilkan dengan pelaksanaan di sekolah melalui pemilihan model pembelajaran yang sesuai. Model pembelajaran tersebut diharapkan mampu mengajarkan pentingnya mengakui dan menilai keragaman sebagai suatu keniscayaan yang harus diterima dan dibangun bersama untuk kepentingan bangsa (Hanum, 2009). Model pembelajaran yang diharapkan mampu memberikan suasana empati terhadap perbedaan latar antara satu kelompok dengan kelompok lainnya.Sehingga model ini dapat peneliti sebut dengan model pembelajaran empati.

Membincang empati dapat kita kutip pendapat Green (1998) yang menyatakan bahwa empati adalah kemampuan memasuki dan memiliki akses atas perasaan dan pikiran orang lain. Empati budaya menurut Dodge (2016) adalah keahlian interkultural yang ditandai oleh kemampuan untuk memahami dan berkomunikasi dengan pikiran dan perasaan orang lain dalam konteks budaya yang berbeda. Pendapat awal para ahli menyatakan bahwa empati sebagai "being" sesuatu yang bersifat genetis dan dibawa individu sejak lahir, sedangkan penelitian terbaru menemukan bahwa kemampuan empati dapat ditujukan melalui perlakuan-perlakuan dalam pembelajaran.

Kremer \& Dietzen 1991, Kohn, 1991 dalam penelitiannya menjelaskan bahwa mencontoh perilaku guru dan menerapkan nilai-nilai yang diajarkannya lebih disukai siswa dalam upaya mengadopsi nilai-nilai empati. Dalam penelitian lain, Haynes \& Avery (1979) menemukan bahwa mengasah perasaan, pemahaman, dan perilaku empati dapat dilakukan melalui pelatihan atau pembelajaran tentang nilai-nilai empati. Dalam penelitian Ahmadi dkk, diuji dampak dari beberapa faktor budaya dan sosial seperti etnosentrisme dan empati budaya pada kecerdasan budaya. Hasilnya menemukan bahwa etnosentrisme dan inisiatif sosial memiliki dampak pada indeks kecerdasan budaya. Penelitian ini juga mengindikasikan bahwa infrastruktur yang 
diperlukan untuk membangun kecerdasan budaya adalah empati budaya, etnosentrisme, dan keterbukaan pada pengalaman.

Penelian Rockwell dkk (2019) menunjukkan bahwa bagi banyak instruktur, empati adalah pusat pemikiran sosiologis. Dengan demikian, menumbuhkan empati pada siswa adalah tujuan kursus yang umum. Dalam artikel ini, kami melaporkan temuan awal dari penilaian perubahan empati selama satu semester pada mahasiswa sarjana $(\mathrm{N}=619)$. Kami menggunakan desain penelitian metode campuran yang menggunakan data instruktur kualitatif untuk menentukan variabel tingkat instruktur independen dan survei siswa untuk mengukur perubahan empati siswa. Kami membandingkan perubahan empati antara siswa yang terdaftar di kelas sosiologi pengantar dengan siswa yang tidak terdaftar di kelas sosiologi dan menguji variabel siswa dan instruktur mana yang memprediksi perubahan empati. Kami menemukan bahwa siswa yang mengambil kelas sosiologi memiliki perubahan empati positif dibandingkan dengan mereka yang tidak. Kami menafsirkan temuan ini sebagai bukti bahwa studi sosiologi mempromosikan pengembangan empati dan mendiskusikan implikasi untuk kelas dan penelitian lebih lanjut.

Hasil penelitian Engbers (2020) menunjukkan bahwa siswa memperoleh banyak aspek yang dianggap sebagai bagian dari konsep empati melalui intervensi pendidikan. Simulasi imersif yang menempatkan siswa dalam peran "orang lain" sangat berdampak, terutama jika mereka menciptakan dilema yang membingungkan dan selanjutnya diikuti oleh refleksi terbimbing.

Model ini menjadi penting ketika di lingkungan sekolah terdapat beragam perbedaan latar belakang yang yang dapat mempengaruhi perilaku dan persepsi religi dan budaya. Latar belakang tersebut dapat berupa ragam agama dan suku bangsa. Sesuai dengan latar belakang permasalahan, maka fokus penelitian ini akan melihat langkah-langkah penerapan model pembelajaran empati yang dapat membangun sekolah berwawasan multikultural.

\section{Metode}

Penelitian ini menggunakan rancangan kajian literatur yang bertujuan untuk mendapatkan informasi tentang konsepsi pembelajaran empati dan pendidikan multikultural. Prosedur yang dilakukan melalui pengumpulan literature buku dan jurnal, membaca dan mencatat, dan membandingkan dan mengolah untuk menghasilkan kesimpulan. Data yang digunakan merupakan data sekunder yang berasal dari berbagai buku, jurnal, artikel ilmiah, literature review yang berisikan tentang konsep empati dan multikultural. Memetakan hasil kajian ke dalam meta analisis jurnal dengan membaca abstrak dan pembahasan dari setiap penelitian terlebih untuk dijadikan bahasan lebih mendalam dan memperkaya hasil penelitian.

\section{Hasil dan Pembahasan}

\section{Rancangan Model}

Model pembelajaran empati merupakan pembelajaran kooperatif yang menghargai perbedaan latar belakang sosial budaya siswa khususnya perbedaan agama dan budaya dengan menuntut kerjasama dan pemahaman bersama atas perbedaan multikultural tersebut. Berdasarkan kajian literatur dan pengalaman peneliti di lapangan, maka pembelajaran tersebut dapat dituangkan secara rinci pada bagan 1 berikut.

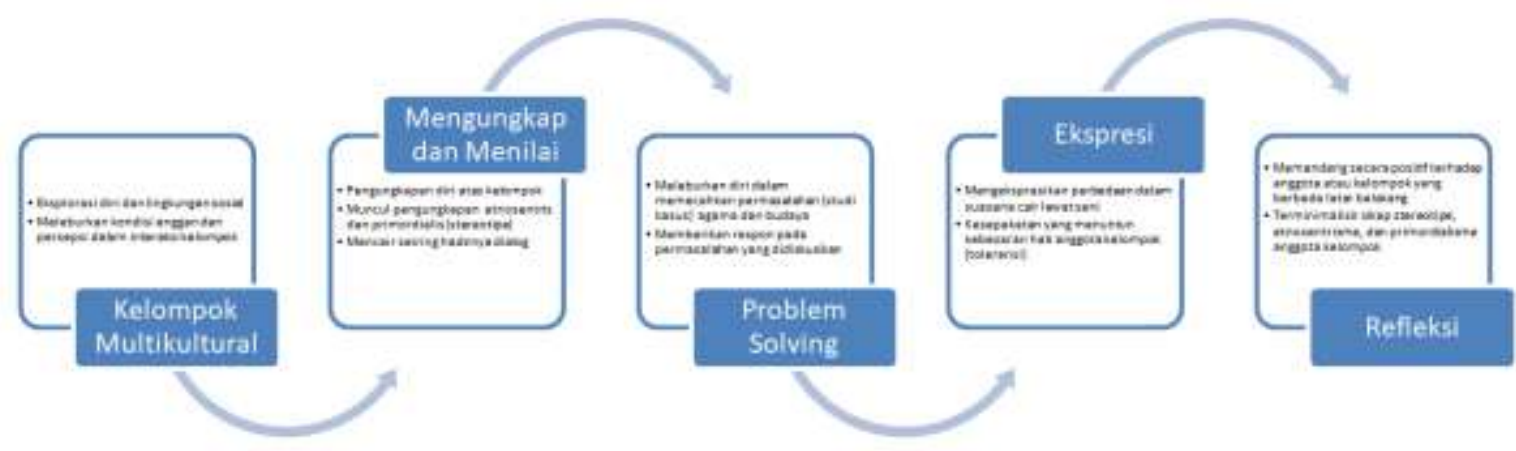

Gambar 1. Model pembelajaran empati 


\section{Implementasi model}

Model pembelajaran empati dilakukan melalui alur pentahapan tindakan pembelajaran kooperatif dalam keutuhan proses pembelajaran. Rincian alur proses model pembelajaran empati terdiri lima tahap yang merujuk pada pendapat Suparlan Al Hakim (2007) dengan rincian sebagai berikut:

\section{Tahap pertama: pembagian kelompok multikultural}

Langkah pertama pembelajaran model empati ini dilakukan dengan membagi kelas dalam beberapa kelompok. Kelas dibagi dalam kelompok-kelompok kecil yang memungkinkan untuk terjadinya proses interaksi berdiskusi. Kelompok tersebut kita sebut dengan kelompok multikultural. Proses pembagian kelompok multikultural ini bertujuan untuk mengeksplorasi diri siswa terhadap lingkungan sosialnya. Pada langkah ini siswa berkecenderungan akan merasa segan untuk bergabung menjadi satu kelompok dengan anggota kelompok yang tidak akrab dikenalnya. Keadaan ini sebagai refleksi dalam kehidupan sehari-hari. Di tengah masyarakat saat melakukan proses interaksi maka yang dibawa dalam pikirannya adalah beragam persepsi tentang latar belakang orang lain orang lain tersebut. Perlu selalu diupakan untuk meleburkan kondisi segan dan persepsi sebagai jalan membuka proses perkenalan untuk menerima keberadaan orang yang berbeda dengan kita. Hal ini sejalan dengan pemahaman John W. Santrock (2007) mendefinisikan pendidikan multikultural adalah pendidikan yang menghargai diversitas dan mewadahi prespektif dari beragam kelompok kultural atas dasar basis regular.

\section{Tahap kedua: mengungkapkan dan menilai latar belakang sosial budaya}

Langkah berikutnya siswa mengungkapkan secara jujur tentang karakteristik latar belakang multikultural kelompok. Kelompok lain dengan jujur pula memberikan pandangan serta penilaian atas keberadaan kelompok yang mengungkapkan. Proses ini dilakukan secara bergiliran dan setiap kelompok mendapatkan kesempatan mengungkapkan dan memberikan pandangan. Proses ini menuntut kesabaran hari (jiwa besar) saat menerima kritikan tentang latar belakang multikultural kita. Dalam realita kehidupan perilaku etnosentrime berupa melebihkan kelompok agama dan budaya sendiri tidak mungkin dihindari. Kondisi ini akan mencair bila proses pengungkapan diri dilakukan suasana dialog yang jujur dan setiap kelompok mempunyai posisi tawar yang sama. Sejalan dengan esensi pembelajaran kooperatif multicultural diharapkan akan mencair kebekuan karena keegoaan kelompok seiring hadirnya dialog dua arah. Setiap kita terkadang harus memaklumi bahwa perilaku stereotipe terhadap budaya sendiri mengingat pola pikir yang telah tertanam dalam diri setiap orang yang telah dibawa sejak lahir.

\section{Tahap ketiga: memecahkan berbagai kasus keragaman sosial budaya}

Pada tahap ini kelompok multikultural memecahkan berbagai kasus atas konsekuensi keragaman sosial budaya. Proses pada tahap ini diharapkan kelompok yang telah terbentuk lebih dalam meleburkan diri dan mengenal satu sama lain. Pembelajaran multikultural dengan model empati memberikan kasus permasalahan agama dan budaya dengan harapan terjadi interaksi yang telah saling mengenal antar anggota kelompok multikultural.

\section{Tahap keempat: mengekspresikan budaya}

Langkah pembejaran pada proses ini setiap kelompok menampilkan suatu atraksi seni yang disepakati. Tujuan penampilan ekspresi seni ini untuk melebur dan mencairkan suasana interaksi dalam kelompok. Proses mencairkan kebekuan dan keegoan salah satu saluran yang dapat menarik hati siswa adalah lewat kegiatan seni. Diperlukan kebesaran jiwa anggota kelompok dalam memilih satu atraksi budaya. Proses keinginan untuk mengedepankan budayanya sendiri akan selalu ada. Dengan belajar bertoleransi untuk menerima kesepakatan maka proses belajar ini akan mengajarkan anggota kelompok multicultural untuk saling menghargai.

\section{Tahap kelima: refleksi pembelajaran}

Langkah pada tahap ini bertujuan terjadi perenungan siswa akan proses kebersamaan yang telah dilakukan. Siswa sudah mampu meleburkan diri dalam anggota kelompoknya. Siswa mampu secara positif memandang akan keberadaan kelompok multikultural siswa lain. Siswa diharapkan telah belajar banyak tentang pentingnya toleransi dan menghargai perbedaan. Melalui proses pembelajaran empati diharapkan juga sikap etnosentrisme dan primordialisme siswa telah terkurangi.

Pengukuran hasil belajar model pembelajaran empati diukur dengan penilaian autentik berupa pengamatan sikap dan proses berinteraksi dalam kelompok, studi kasus, unjuk kerja serta portofolio. Dengan menggunakan penilaian autentik ini dapat memudahkan guru untuk mengetahui pencapaian kompetensi yang telah dikuasai oleh peserta didik. Seorang guru menilai secara keseluruhan ranah berupa ranah kognitif, afektif, dan keterampilan. 
Tabel 1. Gambaran peran dan penilaian proses pembelajaran model empati

\begin{tabular}{|c|c|c|c|c|c|}
\hline \multirow[t]{2}{*}{ No } & \multirow[t]{2}{*}{ Fase/Langkah } & \multicolumn{3}{|c|}{ Peran } & \multirow{2}{*}{$\begin{array}{c}\text { Gambaran } \\
\text { Evaluasi }\end{array}$} \\
\hline & & Guru & Siswa & Orang Tua & \\
\hline 1 & $\begin{array}{l}\text { Pembagian } \\
\text { Kelompok } \\
\text { Multikultural }\end{array}$ & $\begin{array}{l}\text { Memetakan persebaran } \\
\text { latar belakang }\end{array}$ & $\begin{array}{l}\text { Mengikuti arahan } \\
\text { guru dalam } \\
\text { pembagian } \\
\text { kelompok }\end{array}$ & $\begin{array}{l}\text { Mengarahkan akan } \\
\text { kesesuaian latar } \\
\text { belakang sosial } \\
\text { budaya }\end{array}$ & $\begin{array}{l}\text { Proses } \\
\text { beradaptasi } \\
\text { dalam } \\
\text { kelompok }\end{array}$ \\
\hline 2 & $\begin{array}{l}\text { Mengungkapkan dan } \\
\text { Menilai Latar } \\
\text { Belakang Sosial } \\
\text { Budaya }\end{array}$ & $\begin{array}{l}\text { Memediasi antar } \\
\text { kelompok untuk saling } \\
\text { berpendapat }\end{array}$ & $\begin{array}{l}\text { Menyampaikan } \\
\text { dengan apa adanya } \\
\text { segala hal tentang } \\
\text { latar belakang sosial } \\
\text { budaya }\end{array}$ & $\begin{array}{l}\text { Menyampaikan apa } \\
\text { adanya tentang } \\
\text { kelebihan dan } \\
\text { kekurangan latar } \\
\text { belakang sosial } \\
\text { budaya }\end{array}$ & $\begin{array}{l}\text { Proses } \\
\text { kemampuan } \\
\text { menyampaikan } \\
\text { pendapat } \\
\text { dengan data dan } \\
\text { fakta }\end{array}$ \\
\hline 3 & $\begin{array}{l}\text { Memecahkan } \\
\text { Berbagai Kasus } \\
\text { Keragaman Sosial } \\
\text { Budaya }\end{array}$ & $\begin{array}{l}\text { Memilihkan dan } \\
\text { menentukan kasus- } \\
\text { kasus yang tepat untuk } \\
\text { bahan diskusi }\end{array}$ & $\begin{array}{l}\text { Melaksanakan } \\
\text { diskusi berdasarkan } \\
\text { studi kasus yang } \\
\text { telah dipilihkan }\end{array}$ & - & $\begin{array}{l}\text { Proses bekerja } \\
\text { sama dan } \\
\text { berpendapat } \\
\text { dalam } \\
\text { memecahkan } \\
\text { studi kasus }\end{array}$ \\
\hline 4 & $\begin{array}{l}\text { Mengekspresikan } \\
\text { Budaya }\end{array}$ & $\begin{array}{l}\text { Mengarahkan langkah- } \\
\text { langkah penampilan } \\
\text { ekspresi seni }\end{array}$ & $\begin{array}{l}\text { Menyiap dan } \\
\text { menampilkan } \\
\text { ekspresi seni yang } \\
\text { telah disepakati }\end{array}$ & $\begin{array}{l}\text { Memberikan pilihan- } \\
\text { pilihan ekspresi seni }\end{array}$ & $\begin{array}{l}\text { Proses } \\
\text { penampilan } \\
\text { ekspresi seni }\end{array}$ \\
\hline 5 & $\begin{array}{l}\text { Refleksi } \\
\text { Pembelajaran }\end{array}$ & $\begin{array}{l}\text { Memandu proses } \\
\text { mencari manfaat atas } \\
\text { setiap langkah } \\
\text { pembelajaran yang } \\
\text { telah dilalui }\end{array}$ & $\begin{array}{l}\text { Memberikan } \\
\text { pendapat atas } \\
\text { arahan refleksi yang } \\
\text { diberikan guru }\end{array}$ & - & $\begin{array}{l}\text { Proses } \\
\text { menuangkan } \\
\text { pendapat atas } \\
\text { manfaat } \\
\text { pembelajaran }\end{array}$ \\
\hline
\end{tabular}

\section{Kesimpulan}

Lembaga pendidikan yang menghimpun beragam latar belakang siswa menimbulkan konsekuensi dari berinteraksi sesama mereka. Kondisi keragaman yang dibangun atas ragam perbedaan agama, etnik, bahasa, dan budaya dapat memunculkan suasana stereotipe, etnosentris, primordialisme, bahkan konflik yang dapat mewarnai interaksi tersebut. Bila kondisi ini dibiarkan maka akan memunculkan disintegrasi dalam lembaga pendidikan tersebut. Upaya yang dapat dilakukan untuk mengeliminir keadaan tersebut perlu sikap kekuatan ingin bersatu yang mampu menguatkan berbagai elemen yang ada dalam kelompok. Untuk membangun penguatan pernyataan itu, diperlukan model pembelajaran kooperatif yang dapat membangun kesadaran akan perbedaan tersebut ketika proses belajar mengajar berlangsung. Dengan model pembelajaran ini keterampilan siswa dalam proses kerjasama dan belajar menghargai akan berlangsung dengan maksimal. Model pembelajaran yang disebut model pembelajaran empati yang berisi serangkaian langkah-langkah belajar diharapkan mampu memunculkan pemahaman dan menghargai beragam perbedaan ragam sosial orang lain.

\section{Referensi}

Alanay, Hamdi dan Aydın, Hasan. 2016. "Multicultural Education: The Challenges and Attitudes of Undergraduate Students in Turkey", Education and Science, Vol 41, No 184, 169-191.

Alifah, Pipiet. 2018. "Multicultural Education and Humanism Theory as an Effort to Improve the Social Sensibility of Primary School Students", Varia Pendidikan, Vol. 30, No. 1.

Al Hakim, Suparlan. 2007. "Pembelajaran Berbasis Multikultural". Dalam Model-Model Pembelajaran Inovatif. Malang: LP3 UM.

Ambarudin, R. Ibnu. 2016. "Pendidikan Multikultural untuk Membangun Bangsa yang Nasionalis Religius", Jurnal Civics, Vol. 13 No. 1.

Banks, James A. 1989. Multicultural Education: Issues and Perspectives. Boston-London: Allyn and Bacon Press.

Banks, James A. 2007. Educating Citizens In Multicultural Society. Second edition. New York: Teachers College Columbia University.

Blum, Lawrence. 2014. "Three Educational Values for a Multicultural Society: Difference Recognition, National Cohesion and Equality", Journal of Moral Education, Vol. 43, No. 3, 332-344, http://dx.doi.org/10.1080/03057240.2014.922057. 
Bullough Jr, Robert V.. 2015. "Differences? Similarities? Male teacher, female teacher: An instrumental case study of teaching in a Head Start classroom", Teaching and Teacher Education, (47) 13e21.

Colombo, Maddalena. 2012. "Pluralism in Education and the multicultural reality of the schools. How do Italian teachers react?", Sociology of Education Research Network, SOE-RN 10 European Sociological Association Mid-term conference, Department of Sociology, Ghent University, Belgium, $13^{\text {th }}$ and $14^{\text {th }}$ of September 2012.

Dodge, J.A. 2016. But I Wouldnt Do That: Teaching Cultural Empathy, Doctor of Ministry, Paper 127.

Engbers, R.A. 2020. "Students' Perceptions of Interventions Designed to Foster Empathy: An Integrative Review", Nurse Education Today, Volume 86, https://doi.org/10.1016/j.nedt.2019.104325

Gustini, Neng. 2017. "Empati Kultural Pada Mahasiswa", JOMSIGN: Journal of Multicultural Studies in Guidance and Counseling, Volume 1, No. 1. Page 17-34.

Hanum, Farida dan Rahmadonna, Sisca. 2009. "Implementasi Model Pembelajaran Multikultural di Sekolah Dasar di Propinsi Daerah Istimewa Yogyakarta", Artikel Multikultural-Stranas.

Marri, Anand R.. 2010. "Multicultural Democracy: Toward a Better Democracy", Intercultural Education. 14:3, 263277, DOI: $10.1080 / 1467598032000117060$.

Mpofu, Elias, Thomas, Kenneth R. and Chan, Fong. 2004. "Social Competence in Zimbabwean Multicultural Schools: Effects of Ethnic and Gender Differences", International Journal of Psychology, 39 (3).

Nasikun. 2007. Sistem Sosial Indonesia. Jakarta: RajaGrafindo Persada.

Oryan, Shlomit and Ravid, Rachel. 2019. "The Experiences of Pre-Service Teachers Delivering a Study Unit on Multiculturalism, Racism and Prejudice", Teaching and Teacher Education, 86 (2019) 102911.

Rambitan, Vandalita Maria Magdalena. 2012. "Strategi Pembelajaran Berpola Pemberdayaan Berpikir Melalui Pertanyaan Dipadu Think Pair and Share dalam Memberdayakan Sikap Sosial Siswa Multietnis", Jurnal Bionature, Volume 13, Nomor 1.

Rockwell, A., Vidmar, C.M., Harvey, P., and Greenwood, L. 2019. "Do Sociology Courses Make More Empathetic Students? A Mixed-Methods Study of Empathy Change in Undergraduates", Teaching Sociology, 1-19.

Santrock, John W.. 2007. Psikologi Pendidikan, Terj. Tri Wibowo B.S. Jakarta: Kencana.

Sharma, Sunita. 2015. "Multicultural Education: Teachers"e Perceptions And Preparation", Journal Of College Teaching and Learning. Volume 2, Number 5.

Sudrajat. 2014. "Pendidikan Multikultural untuk Meningkatkan Kualitas Pembelajaran IPS di Sekolah Dasar", JIPSINDO, No. 1, Volume 1.

Suparlan, Parsudi. 2002. "Menuju Masyarakat Indonesia yang Multikultural". Jurnal Antropologi Indonesia, hlm.98-105.

The Global Education Monotoring Report Team. 2019. Gender Report: Building Bridges for Gender Equality. France: UNESCO.

Vervaet, Roselien, Houtte, Mieke Van, Stevens, Peter A.J. . 2018. "Multicultural School Leadership, Multicultural Teacher Culture and the Ethnic Prejudice of Flemish Pupils", Teaching and Teacher Education. 76.

Voronchenko, Tatiana, Klimenko, Tatiana, Kostina, Irina. 2015. "Learning To Live In A Global World: ProjectBased Learning In Multicultural Student Groups As A Pedagogy of Tolerance Strategy", Procedia - Social and Behavioral Sciences, 191.

Wahyuandari, Wenni dan Rahmawati, Desi. 2014. "Pendidikan Multikultural (Studi Kasus di Sekolah Lanjutan Tingkat Pertama (SLTP) di Tulungagung”. Jurnal Universitas Tulungagung BONOROWO Vol. 2.No.1.

Wahyuni, Imelda. 2015. "Pendidikan Multikultural: Upaya Memaknai Keragaman Bahasa di Indonesia", Zawiyah Jurnal Pemikiran Islam, Vol. 1 No. 1.

Widiatmoko, Anggoro. 2017. "Pengaruh Kemampuan Empati Terhadap Perilaku Proposial Siswa Sekolah Dasar", Jurnal Pendidikan Guru Sekolah Dasar Edisi 10 Tahun ke-6. 